Article

\title{
Rusty Blackbird Habitat Selection and Survivorship during Nesting and Post-Fledging
}

\author{
Patricia J. Wohner ${ }^{1, *}$, Carol R. Foss ${ }^{1}$ and Robert J. Cooper ${ }^{2}$ \\ 1 New Hampshire Audubon, Concord, NH 03301, USA; cfoss@nhaudubon.org \\ 2 Warnell School of Forestry, University of Georgia, Athens, GA 30602, USA; rcooper@warnell.uga.edu \\ * Correspondence: pjwohner@gmail.com
}

Received: 13 May 2020; Accepted: 29 May 2020; Published: 2 June 2020

\begin{abstract}
Rusty blackbird (Euphagus carolinus) populations have declined dramatically since the 1970s and the cause of decline is still unclear. As is the case for many passerines, most research on rusty blackbirds occurs during the nesting period. Nest success is relatively high in most of the rusty blackbird's range, but survival during the post-fledging period, when fledgling songbirds are particularly vulnerable, has not been studied. We assessed fledgling and adult survivorship and nest success in northern New Hampshire from May to August in 2010 to 2012. We also assessed fledgling and adult post-fledging habitat selection and nest-site selection. The likelihood of rusty blackbirds nesting in a given area increased with an increasing proportion of softwood/mixed-wood sapling stands and decreasing distances to first to sixth order streams. Wetlands were not selected for nest sites, but both adults and fledglings selected wetlands for post-fledging habitat. Fledglings and adults selected similar habitat post-fledging, but fledglings were much more likely to be found in habitat with an increasing proportion of softwood/mixed-wood sapling stands and were more likely to be closer to streams than adults. No habitat variables selected during nesting or post-fledging influenced daily survival rates, which were relatively low for adults over the 60-day study periods (males 0.996, females 0.998). Fledgling survival rates (0.89) were much higher than reported for species of similar size.
\end{abstract}

Keywords: Euphagus carolinus; nest success; post-fledging; rusty blackbird; survivorship; streams; wetlands

\section{Introduction}

Songbird breeding productivity is often measured by nest success and associated habitat characteristics [1]. However, mortality during the post-fledging period can also result in low breeding productivity and limit populations even when nest success is high [2,3]. Juvenile songbird survivorship is typically estimated to be $50-60 \%$ of adult survivorship [4,5]. However, actual juvenile survival rate estimates are quite variable, ranging from 0.19 in hooded warblers (Setophaga citrina) to $>0.65$ in ovenbird (Seiurus aurocapilla) and worm-eating warbler (Helmitheros vermivorum; [1,3]. Despite this potential variability in survivorship, the post-fledging period remains an understudied component of avian demographics for many species in part due to difficulties of following individuals after fledging [5-9].

Differences in food requirements and vulnerability to predators between the nesting and post-fledging periods may lead to differences in habitat selection between these stages of the breeding season $[7,10,11]$. For example, ovenbird, worm-eating warbler, hooded warbler, Acadian flycatcher (Empidonax virescens), cerulean warbler, red-eyed vireos (Vireo olivaceus), and Swainson's thrush (Catharus ustulatus) families all move to stands with greater structural complexity following fledging [1,2,11-15]. High mortality rates are associated with this movement as young birds seek better-suited post-fledging 
habitat [6,7]. Therefore, full assessment of breeding habitat quality requires evaluation of post-fledging habitat selection and survival [16].

The rusty blackbird (Euphagus carolinus) is a continental migrant that breeds primarily in the boreal forests of Canada and Alaska, with populations in Acadian forests of northern New England and eastern Canada [17] and northern New York [18,19]. The species has experienced an estimated 85-95\% continent-wide population decline with accelerated decline rates beginning in the early 1970s [20-24]. It has been declared a species of conservation concern by the United States Fish and Wildlife Service [25] and is considered vulnerable to extinction by the International Union for the Conservation of Nature [26]. Reasons for the decline remain unclear despite extensive study on both the breeding and wintering grounds. However, habitat use and survivorship during the post-fledging period have not been studied.

Nest success is relatively high where studied in Alaska $(\bar{x}=0.56$ [27]) and New England $(\bar{x}=0.62$ [28], $\bar{x}=0.53$ [29]), and rusty blackbirds do not seem to be suffering from chronically low rates of nest success. Rusty blackbird nest success estimates are much higher than the $0.30-0.39$ estimated for red-winged (Agelaius phoeniceus), yellow-headed (Xanthocephalus xanthocephalus), and Brewer's (Euphagus cyanocephalus) blackbirds, which have not experienced dramatic declines [30].

Rusty blackbirds typically nest in young spruce-fir stands with high stem densities and forage for aquatic invertebrates such as Ephemeroptera, Odonata, Plecoptera, Diptera, and Tricoptera [17,31] in shallow wetlands or along stream edges $[17,28,29,31]$. Previous studies have identified percent cover of young softwood stands to be the most important variable selected for nest sites at multiple scales and associated with higher survival [27-29]. However, wetlands were not selected for nesting at the $5 \mathrm{~m}$ or $500 \mathrm{~m}$ radius scale even though the species is well-known as a wetland obligate [17].

Understanding the roles of both wetlands and young softwood stands could have important consequences for research and management. Dense spruce-fir sapling stands are selected for concealment during nesting and the first few days after fledging. Similar to many songbird species, young rusty blackbird fledglings fly poorly and lack the ability to escape predation in the first week or so after leaving the nest [8]. Before they become capable of sustained flight, fledglings spend much of their time on or near the ground, where they are easy prey for predators $[2,3,7,10,32]$. As energetic demands increase [33] and fledglings become more mobile, proximity to wetlands and streams with abundant and diverse invertebrate resources becomes important as fledglings learn to forage independently and fulfill their high energetic demands $[6,7,31,33]$.

Our objectives were to 1 ) determine what forest stand types are important to rusty blackbirds during nesting and post-fledging, 2) assess nest site and post-fledging habitat selection, 3) analyze the influence of selected habitat characteristics on nest success and post-fledging survivorship of fledglings and adults, 4) provide forest management recommendations for incorporating post-fledging habitat into management plans for rusty blackbirds, and 5) advocate a paradigm shift from wetland-centric to landscape-centric for future rusty blackbird researchers in New England, New York, and Maritime Canada.

\section{Materials and Methods}

\subsection{Study Area}

We studied rusty blackbirds during 2010-2012 in the upper Androscoggin River watershed in northern New Hampshire. Ecosystem classification places this watershed within the White Mountains Section of the New England-Adirondack Province [34]. The landscape is mountainous, with most of the area at elevations between 460 to 800 m.a.s.l., valleys between 305 to 460 m.a.s.l., and a few peaks and ridges exceeding 800 m.a.s.l. [35]. Surface waters include the 6th order Androscoggin and Magalloway rivers, 4th order Clear Stream and Swift Diamond River, numerous lower order streams, Umbagog Lake (3177 ha), and several ponds of 10 to $125 \mathrm{ha}$. Climatic conditions include cold winters and warm summers, with mean monthly lows ranging from $-15^{\circ} \mathrm{C}$ to $13^{\circ} \mathrm{C}$ and highs from $-3.3^{\circ} \mathrm{C}$ to 
$25.6^{\circ} \mathrm{C}$ in January and July, respectively; mean annual precipitation is $105 \mathrm{~cm}$, with a monthly means ranging from $5.9 \mathrm{~cm}$ in February to $11.1 \mathrm{~cm}$ in October, and $198 \mathrm{~cm}$ of snowfall [36].

The area is heavily forested in a patchwork of northern hardwood, Acadian spruce-fir, and mixed northern hardwood-spruce-fir. Balsam fir (Abies balsamea) and red spruce (Picea rubens) dominate softwood stands; eastern white pine (Pinus strobus), black spruce (Picea mariana), northern white cedar (Thuja occidentalis), and tamarack (Larix laricina) occur at lower densities. Major hardwood species include sugar maple (Acer saccarum), red maple (Acer rubrum), yellow birch (Betula alleghaniensis), white birch (Betula papyrifera), quaking aspen (Populus tremuloides), bigtooth aspen (Populus grandidentata), balsam poplar (Populus balsamifera), American beech (Fagus grandifolia), black cherry (Prunus serotina), pin cherry (Prunus pensylvanica), American mountain-ash (Sorbus americana), striped maple (Acer pensylvanicum), white ash (Fraxinus americana), and black ash (Fraxinus nigra). Primary stand disturbance agents include timber harvesting, wind throw, breakage from ice and snow loads, beavers (Castor canadensis), and insect outbreaks, notably spruce budworm (Choristoneura spp.) [35].

We conducted our study in three drainages: 1) Swift Diamond River valley (SWDI), 2) Mollidgewock (MOLL), and 3) Interior (INTE). SWDI was located on Wagner Forest Management Ltd. lands (hereafter Wagner) and INTE and MOLL were located on the Umbagog National Wildlife Refuge (hereafter Umbagog; Figure 1).

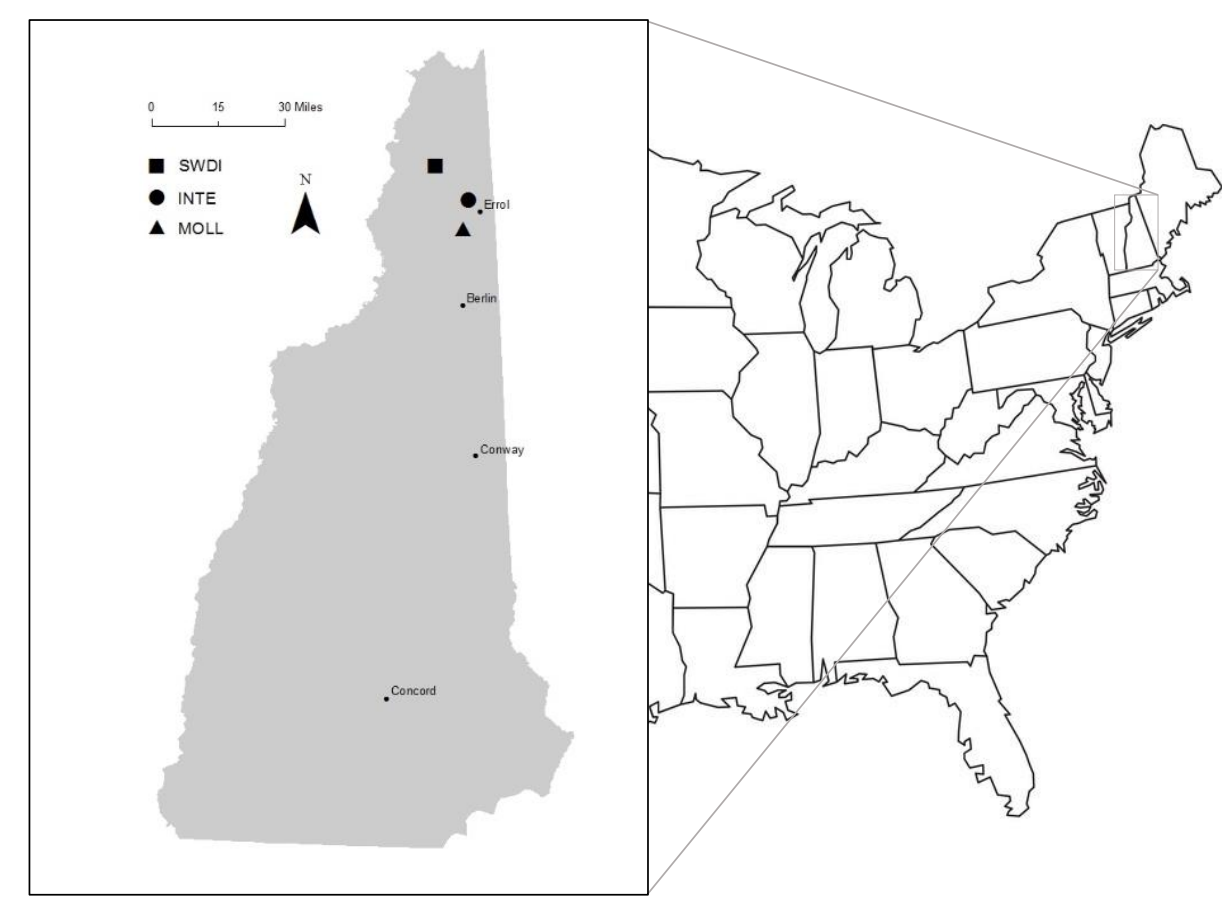

Figure 1. Drainages and their locations relative to the nearest township of Errol, Coos County, New Hampshire within the USA. Symbols indicate approximate site locations from 2010-2012 and include Swift Diamond (SWDI), Interior (INTE), and Mollidgewock (MOLL).

\subsection{Field Procedures}

During our pilot study in 2010, we conducted presence-absence surveys within $100 \mathrm{~m}$ of wetlands by observing passively for $3 \mathrm{~min}$, broadcasting male rusty blackbird songs and calls for $38 \mathrm{~s}$, and observing passively for another $5 \mathrm{~min}$ [28]. We discovered that these surveys failed to detect previously located rusty blackbird pairs that were nesting $>100 \mathrm{~m}$ from wetlands. Thus, we changed our survey protocol for 2011 and 2012 to include regenerating softwood stands up to approximately $0.5 \mathrm{~km}$ from wetlands during $30 \mathrm{~min}$ to $2 \mathrm{~h}$ passive surveys [27]. We identified survey locations using a combination of forest industry maps, topographic maps, and Google Earth imagery. We began nest-searching in early May in areas of rusty blackbird activity and continued through mid-June. 
Once located, nests were monitored approximately every 5 days until they either fledged young or failed. When nests failed during incubation, we attempted to locate re-nests.

To collect spatial and survival data on fledgling and adult rusty blackbirds, we deployed radio-transmitters on a subset of nestling and adult rusty blackbirds captured at nest sites; not all nests received transmitters. We attached VHF transmitters to nestlings when they were approximately 7-10 days old. We captured adult rusty blackbirds near active nests using 60-mm mesh size, $6 \mathrm{~m}$ long mist nests, and a broadcast call. We used transmitters from Blackburn Transmitters (Nacogdoches, TX, USA), Advanced Telemetry Systems (Isanti, MN, USA), and Holohil Systems, Ltd. (Carp, ONT, CA). Battery life ranged from 30 days in 2010 to 60 days in 2012. Transmitters were attached via a synsacrum harness with a degradable $1 \mathrm{~mm}$ stretchy jelly cord [37]. In 2012, we designed a harness with a weak link because birds returned with harnesses from previous years that had become embedded in their skin.

Transmitter weight with harness varied from $1.8 \%$ (70 g bird) to $2.3 \%$ ( $55 \mathrm{~g}$ bird) of adult bird mass. Transmitters on nestlings weighed from 5.6 to $8 \%$ of mass at time of attachment but were lower than adult ratios once nestlings fledged because transmitters used on fledglings were lighter $(0.9 \mathrm{~g})$ than those for adults $(2.7 \mathrm{~g})$. Harnesses were fitted loosely on nestlings and were the largest size to enable growth. Each adult and nestling blackbird received a US Geological Survey (USGS) federal band and adults received a unique color-band combination for identification (USGS BBL Permit \# 22665). This study plan was approved by the University of Georgia IACUC (AUP\# A2009 1-003).

Observers located tagged rusty blackbirds 3-5 times per week using ATS R2000 and R2100 receivers in vehicles with roof-mounted dipole antennas and hand-held R410 receivers with three-element Yagi antennas. In $>94 \%$ of locations, we determined coordinates with a Garmin GPS by following a radio signal until we saw or heard the bird. In remaining cases, we used triangulation of bearings taken from multiple points on logging roads. We conducted observations between sunrise and sunset and avoided periods of excessive wind and rain.

\subsection{Data Analyses}

\subsubsection{Habitat Selection}

We used binomial logistic regression to determine habitat characteristics that rusty blackbirds used out of proportion to availability [38]. We conducted separate analyses for nests, fledgling, and adult telemetry locations. Nests or telemetry locations were considered use points and we generated random availability points within rusty blackbird areas of use with ARCMAP 10.4. We then assigned a value of 1 to use points and 0 to availability points to be used as response variables. If multiple tagged birds were documented at the same location at the same time, we only used a location once for a use point and prioritized triangulated points for removal.

To generate availability points, we created a $90 \%$ kernel density background for each of the three analyses and the three drainages separately. For the post-fledging analysis, the background area of use included area outside nesting sites because fledglings moved increasing distances $(>1 \mathrm{~km})$ from the nest as they became more mobile. We generated roughly the same number of availability points as use points. We constrained availability points to be at least $50 \mathrm{~m}$ apart for telemetry data and $300 \mathrm{~m}$ apart for nests. Availability points within large bodies of open water or other unsuitable habitats (e.g., paved road surfaces, buildings) were deleted and not replaced.

We created predictor habitat variables based on published literature [24-26,38], our field observations, habitat characteristics used in our revised survey protocol, and relevance to forest management. We generated predictor variables for SWDI from layers we created in ARCMAP 10.4 using forest stand maps (Wagner), and soil, river, and wetland maps from New Hampshire Geographically Referenced Analysis and Information Transfer System (NH GRANIT, hereafter GRANIT; Table 1). For MOLL and INTE, where forest stand maps were unavailable, we used aerial photography to digitize forest stand types within a $30 \mathrm{~m}$ radius around use and paired availability points for each habitat variable for every other telemetry point/bird/day. 
Table 1. Descriptions of habitat variables used for generating logistic regression models for rusty blackbird nests and post-fledging adult and fledgling locations in northern New Hampshire from 2010-2012. Buffer is a $30 \mathrm{~m}$ radius circle around location points.

\begin{tabular}{cc}
\hline Variable & Description \\
\hline lowdrainage & $\%$ of buffer in class poorly and very poorly drained \\
lowslope & $\%$ of buffer that is 1-8\% slope \\
stream123 & mean distance of buffer to 1st-3rd order streams \\
stream3456 & mean distance of buffer to 3rd-6th order streams \\
allstreams & mean distance of buffer to 1st-6th order streams \\
softwood & $\%$ softwood stands in buffer \\
swsaplings & \% softwood or mixed softwood $(>75 \% \mathrm{SW})$ \\
mixage & $\%$ mixed-age stands in buffer \\
wetlands & $\%$ any vegetated palustrine wetland in buffer \\
alder & $\%$ alder wetland in buffer \\
beaver & $\%$ beaver pond wetland buffer \\
forestwl & $\%$ forested wetland in buffer \\
seasonfl & $\%$ seasonally flooded wetland in buffer \\
\hline
\end{tabular}

${ }^{1}$ swsaplings were stands $<10$ yrs old or with saplings 1.3-14 cm DBH.

Once we created predictor variables, we extracted raster data for every other point/day/bird (due to time and computing constraints and to match Umbagog data) for the 13 variables (Table 1). We calculated values for predictor variables as the mean of raster cell values in a $30 \mathrm{~m}$ radius buffer around use and availability points. The $30 \mathrm{~m}$ scale is roughly an order of magnitude between the 5 and $500 \mathrm{~m}$ scales used as buffers for variables in previous research [28,29]. To summarize variables, we calculated the mean and standard deviation of use and availability points for nests and blackbird locations.

We used generalized linear mixed models (GLMM; R package lme4) in program R 3.4.3 [39] to run logistic nest site and post-fledging habitat selection analyses [40]. We determined Pearson correlations on all pairs of predictor variables prior to modeling and avoided including variables correlated at $r>0.40$ in the same model. We used Akaike information criterion (AICc) to compare model fit between nested models with and without year as a random effect and determined that year did not account for significant variation. For post-fledging telemetry data, we included individual birds nested within drainage (SWDI, INTE, MOLL) as a random effect in each model to control for spatial autocorrelation [40]. Availability points were assigned to individual birds based on location. We did not consider pseudoreplication to be a problem because blackbirds did not maintain a consistent home range post-fledging. We did not include fledglings and adults from the same nest in the same analysis, randomly omitting one.

We used model selection to evaluate the relative plausibility of habitat selection models with combinations of the 13 predictor variables [41,42]. To avoid over-fitting models with parameters, we first reduced our set of 13 variables by comparing correlated sets individually with the second-order AICc. We retained variables for further analysis that had the lowest AICc scores and were better than the null model. We included one stream, wetland, and forest stand type variable in a model at a time to avoid correlation and then compared 17 candidate models. The top habitat selection models for males and females included the same variables with similar weights, and parameter estimates were similar, so we pooled males and females into adults for habitat selection analyses.

We assessed the relative fit of each candidate model by calculating Akaike weights (wi; [42]. We report a confidence set of models that included only those candidate models with Akaike weights that were within $10 \%$ of the largest weight [43] for evaluating strength of evidence. If more than 3 models were within $10 \%$ of the model with the greatest $\omega$ i, we report the subset of models with $\omega i>$ 0.01. To choose the best model in analyses that generated several top models, we chose the model with the fewest parameters within $\triangle \mathrm{AICc}<2$ of the top model. We chose the top model if the level of support $(\omega \mathrm{i}>0.6)$ indicated that it was far better than other models. 
We used the chi-square $G$ statistic to evaluate the strength of our top models in explaining goodness-of-fit $(p<0.05 ;[44])$. We assessed the predictive ability of our top models by estimating the Area Under the Curve (AUC) of the Receiver Operating Characteristic (ROC) curve, i.e., the rate of true positives (sensitivity) to false positives (1-specificity). We plotted ROC curves with the R package "pROC". We used an AUC $\geq 0.85$ to indicate good predictive ability of our models.

We assessed the precision of model-averaged coefficients by calculating $95 \%$ confidence intervals. Confidence intervals including 1 indicated inconclusive estimates because we could not determine the nature of the relationships (i.e., whether positive or negative) due to imprecision in parameter estimates [45]. We report scaled, model-averaged coefficients from the top models ( $\omega \mathrm{i}>0.6$ ). The scalars correspond to biologically relevant unit changes in predictors.

\subsubsection{Nest Success and Adult and Fledgling Survivorship}

We used the R package RMark 2.2.4 [46] to estimate daily survival for nests, fledglings, and adults. We used nest success models appropriate for use with telemetry data when data are not collected at a consistent time interval and the exact date of fates are not known $[47,48]$. For nest success, we considered the first day we observed eggs, incubation behavior, or nestlings to be the date the nest was found. We assumed a 29-day exposure time when calculating nest success; 5 days for laying, 12 days for incubation, and 12 days for nestlings [28]. We considered the date of fledging to be the "date found" in RMark for both adults and fledglings. Tagged nestlings that were depredated before they fledged were not included.

Covariates tested included variation in survival among years (2010,2011, and 2012), among drainages (SWDI, MOLL, INTE), and with number of days since nest initiation (nests). To determine fledgling survival in the first week, we assessed seasonal survival of fledglings (season). We did not include adult age as a covariate because only two adults could be aged beyond the after-hatch-year class. We included habitat variables from top models from nest and post-fledging habitat selection analyses. We used overall means to interpolate habitat variables for 9 blackbirds that were missing habitat data to enable daily survival rate calculations for those individuals. To account for classes with no mortality, i.e., survivorship $=1$ and variance cannot be estimated, we added a fictitious bird to the dataset in that class and assumed the bird died on the last occasion [28]. We assigned mean habitat covariate values to this bird. We calculated the mean of all use locations for each habitat variable to include in the corresponding survival record for each bird and assumed the mean was representative of variables leading up to predation or survival. We used a model selection approach to determine the best model for nest success and blackbird survival, such as the methods described above for habitat selection.

\section{Results}

\subsection{General}

We found 59 rusty blackbird nests during the 2010-2012 breeding seasons, the majority of which $(92 \%)$ were in previously clear-cut, regenerating softwood-dominated stands $5-15$ years post-harvest. These stands averaged 5.4 ha and ranged from $0.36-13$ ha. Of the 59 nests in our study, 31 (53\%) were within $75 \mathrm{~m}$ and $10(17 \%)$ were $>200 \mathrm{~m}$ from a stream or wetland.

We used 37 nest locations that were $>100 \mathrm{~m}$ apart and generated 57 random availability points to use in logistic regression. We attached 36 radio-transmitters to adults ( 13 female, 23 male) and 25 to nestlings. After removing adult birds tagged from the same nests, we were left with points from 11 females and 18 males. Of the 25 nestlings tagged, 8 died before fledging. In the seven cases where two nestlings from a nest had transmitters, one of the two was omitted from the fledgling analysis, leaving 10 fledglings in the habitat selection analysis. We documented a total of 318 use locations for 20 blackbirds in 2010, 993 use locations for 24 birds in 2011, and 626 use locations for 17 birds in 2012 (Appendix A). We omitted location points for one female who died from apparently capture-related causes. We omitted 70 location points of adults and fledglings documented when fledglings were still 
in the nest to eliminate data from the nestling period. After refining the telemetry data, 771 use points remained, and we generated 806 availability points.

New fledglings flew weakly and most remained within $100 \mathrm{~m}$ of the nest for the first few days after fledging. Once fledglings moved away from the nesting area, we observed pairs dividing their fledglings between them, joining other family groups, and feeding fledglings of other pairs. Most fledglings depended on adults for food for about 3 weeks. Some fledglings traveled alone after becoming independent, while others remained in family groups or joined up with fledglings from their own or other families. During our study, all tagged individuals that fledged before 8 June had been detected more than $1 \mathrm{~km}$ from the nest by the end of the month.

\subsection{Habitat Selection}

The top model for habitat selection included similar variables for all 3 groups tested (i.e., nest sites, fledglings, and adults): distance to streams, proportion of softwood/mixed-wood sapling stands, wetlands, and low slope class (Table 2). In each case, the top model received strong support ( $\omega \mathrm{i}>0.62$; Table 2). However, parameter estimates differed substantially among the groups, justifying not pooling adults and fledglings in the same analysis (Table 3).

Table 2. High ranking candidate models for rusty blackbird nesting, fledgling, and adult habitat selection in Northern New Hampshire from 2010-2012. $k$ = number parameters, AICc = Akaike information criterion for small sample sizes, $\triangle \mathrm{AICc}$ is the difference between the model and top model, $\omega \mathrm{i}=$ weight cum., $\omega \mathrm{i}=$ cumulative weight, and $\mathrm{LL}=\log$ likelihood. See Table 1 for variable definitions.

\begin{tabular}{|c|c|c|c|c|c|c|}
\hline Candidate Models & $\mathbf{k}$ & $\mathrm{AICc}$ & $\Delta \mathrm{AICc}$ & $\omega \mathbf{i}$ & cum. wi & LL \\
\hline \multicolumn{7}{|l|}{ Nesting } \\
\hline allstreams+swsaplings+lowslope & 5 & 93.28 & 0 & 0.62 & 0.62 & -41.3 \\
\hline allstreams+swsaplings+lowslope+wetlands & 6 & 95.24 & 1.95 & 0.23 & 0.85 & -41.14 \\
\hline stream123+swsaplings+lowslope+wetlands & 6 & 96.81 & 3.53 & 0.11 & 0.96 & -41.92 \\
\hline allstreams+swsaplings+wetlands & 5 & 99.54 & 6.25 & 0.03 & 0.99 & -44.43 \\
\hline Null & 2 & 130.16 & 36.87 & 0 & 1 & -63.01 \\
\hline \multicolumn{7}{|l|}{ Fledgling } \\
\hline allstreams+swsaplings+lowslope+wetlands & 6 & 404.91 & 0 & 0.73 & 0.73 & -196.35 \\
\hline allstreams+swsaplings+lowslope+wetlands+softwood & 7 & 406.97 & 2.06 & 0.26 & 0.99 & -196.34 \\
\hline Null & 3 & 543.62 & 138.71 & 0 & 1 & -268.78 \\
\hline \multicolumn{7}{|l|}{ Adult } \\
\hline allstreams+swsaplings+lowslope+wetlands & 6 & 1164.69 & 0 & 0.73 & 0.73 & -576.31 \\
\hline allstreams+swsaplings+lowslope+wetlands+softwood & 7 & 1166.68 & 1.99 & 0.27 & 0.99 & -576.29 \\
\hline allstreams+mixage+lowslope+wetlands+softwood & 7 & 1174.46 & 9.77 & 0.01 & 1 & -580.18 \\
\hline Null & 3 & 1568.82 & 404.13 & 0 & 1 & -781.40 \\
\hline
\end{tabular}

Distance to 1st-6th order streams was an important variable in all 3 analyses, and had the largest effect for fledglings (Figure 2, Table 3). Fledglings were 4.6 times more likely to occur with every $50 \mathrm{~m}$ decrease in distance from streams, compared to 1.2 times more likely for adults and 1.3 times for nest sites. Nests, fledglings, and adults were all 1.2 times more likely to occur with every $10 \%$ increase in softwood/mixed-wood sapling stands. Only nests were influenced by low slope and were 1.1 times more likely to be observed with a $10 \%$ increase in area with low slope. While the proportion of wetlands in an area was important for fledgling and adult habitat use, (blackbirds were 1.3 times more likely with each $10 \%$ increase), wetlands were not important for nest-site selection (Figure 2). 
Table 3. Adjusted, scaled back-transformed log-odds estimates for rusty blackbird fledglings $(\mathrm{n}=10)$, adults ( $n=29)$, and nests $(n=37)$ in New Hampshire from 2010-2012 including estimates, SE, and 95\% upper and lower confidence intervals. Scaled log odds estimate reads: it is 1.3 times more likely a rusty blackbird will be present with every $10 \%$ increase in the proportion of sapling stands in a 30 m radius buffer. Confidence limits including 1 indicate no effect and are denoted "-".

\begin{tabular}{|c|c|c|c|c|c|c|c|}
\hline Variable & Estimate & SE & LCI & UCI & $\begin{array}{l}\text { Unit } \\
\text { Change }\end{array}$ & $\begin{array}{c}\text { Scaled } \\
\text { Estimate }\end{array}$ & Scaled CL \\
\hline \multicolumn{8}{|l|}{ Fledglings } \\
\hline Intercept & -0.92 & 0.38 & -1.66 & -0.18 & & & \\
\hline distance to streams (1st-6th) & -30.3 & 7.76 & -45.5 & -15 & $50 \mathrm{~m}$ & 4.55 & $2.1,9.7$ \\
\hline proportion swsaplings & 1.8 & 0.34 & 1.1 & 2.4 & $10 \%$ & 1.2 & $1.1,1.3$ \\
\hline proportion low slope $(1-8 \%)$ & 1.18 & 0.3 & 0.59 & 1.77 & - & - & \\
\hline $\begin{array}{l}\text { proportion wetland } \\
\text { Adults }\end{array}$ & 2.9 & 0.6 & 1.71 & 4 & $10 \%$ & 1.33 & $1.2,1.5$ \\
\hline Intercept & -0.33 & 0.15 & -0.62 & -0.04 & & & \\
\hline distance to streams (1st-6th) & -3.7 & 0.4 & -4.4 & -2.9 & $50 \mathrm{~m}$ & 1.2 & $1.2,1.3$ \\
\hline proportion swsaplings & 1.2 & 0.2 & 0.83 & 1.56 & - & - & \\
\hline proportion low slope $(1-8 \%)$ & 0.87 & 0.2 & 0.56 & 1.17 & - & - & \\
\hline $\begin{array}{l}\text { proportion wetland } \\
\text { Nests }\end{array}$ & 2.7 & 0.4 & 1.95 & 3.38 & $10 \%$ & 1.31 & $1.2,1.4$ \\
\hline Intercept & -0.87 & 0.55 & -1.95 & 0.21 & & & \\
\hline distance to streams (1st-6th) & -5.16 & 1.65 & -8.39 & -1.93 & $50 \mathrm{~m}$ & 1.3 & $1.1,1.5$ \\
\hline proportion swsaplings & 0.02 & 0.01 & 0.01 & 0.04 & $10 \%$ & 1.2 & $1.1,1.5$ \\
\hline proportion low slope $(1-8 \%)$ & 0.01 & 0.01 & 0 & 0.03 & $10 \%$ & 1.1 & $1,1.3$ \\
\hline proportion wetland & 0.01 & 0.01 & -0.02 & 0.04 & - & - & \\
\hline
\end{tabular}

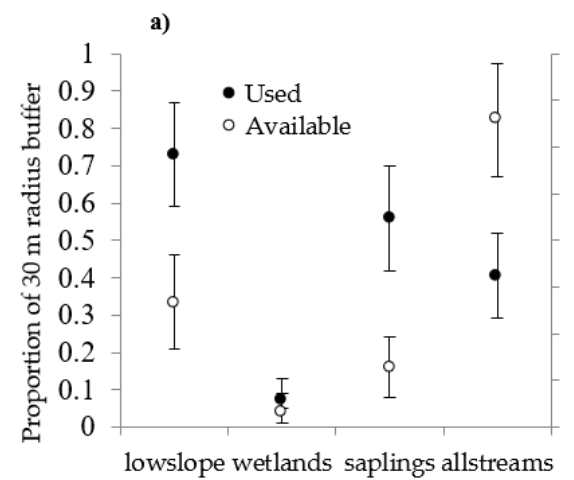

c)

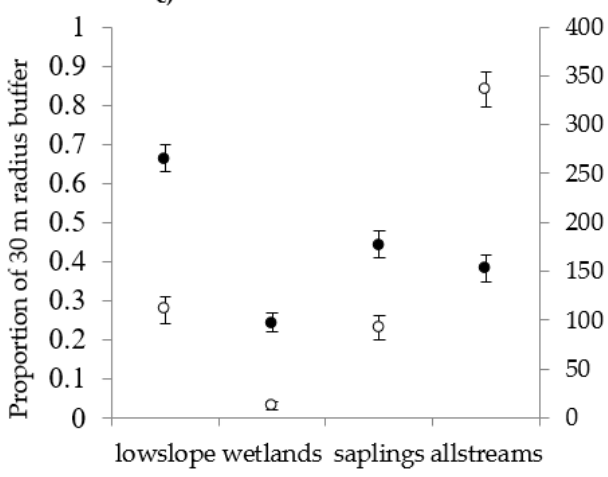

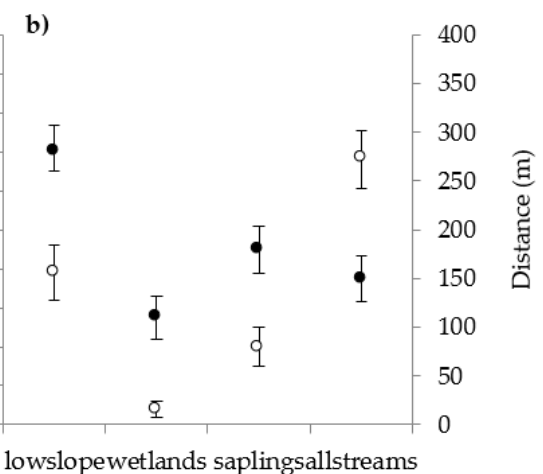

lowslopewetlands saplingsallstreams

Figure 2. Mean and 95\% CI of variables from top models of (a) nest use (black circles; $\mathrm{n}=37$ ) relative to availability (white circles; $\mathrm{n}=57$ ), (b) fledgling habitat use (black circles; $\mathrm{n}=198$ ) relative to availability (white circles; $n=196$ ), and (c) adult use (black circles; $\mathrm{n}=537$ ) relative to availability (white circles; $n=609$ ) in N. New Hampshire from 2010-2012. Proportion of lowslope, wetlands, and softwood/mixed-wood saplings are on the left $y$-axis, and distance $(\mathrm{m})$ of points from allstreams is on the right $x$-axis. Lowslope $=\%$ of $30 \mathrm{~m}$ buffer in soil class poorly or very poorly drained, wetlands $=\%$ of $30 \mathrm{~m}$ buffer in any vegetated palustrine wetland, saplings $=\%$ of $30 \mathrm{~m}$ buffer in softwood/mixed-wood sapling stands, and allstreams = mean distance of buffer to 1st-6th order streams. 


\subsection{Nest Success}

We included 37 nests with known outcomes that were $>100 \mathrm{~m}$ apart in the nest success analysis. The null model for nest survival received most of the support (Table 4); candidate models including year, drainage, and trend through time (season) received little support (Table 4). Daily nest survival for all years combined was $0.975, \mathrm{SE}=0.26$, resulting in an overall nest success rate with 29-day exposure of 0.48 (Table 4). Although the top model for nest success included wetlands (Table 4), the confidence limits for the estimate of this variable included 0 . We therefore chose the intercept only model as the top model and report estimates from this model (Table 5).

Table 4. High-ranking candidate models for rusty blackbird fledgling, adult, and nest survival in northern New Hampshire. $\mathrm{k}=$ number of parameters, AICc $=$ Akaike information criterion adjusted for small sample sizes, $\triangle \mathrm{AIC}$ is the difference between the model and the top model, $\omega \mathrm{i}=$ weight, and cum. $\omega \mathrm{i}=$ cumulative weight; see Table 1 for habitat variable descriptions. nestage is the age of the nest when first found, $S=$ survival, time = time from first day of study, hy = fledgling, SWDI = Swift Diamond drainage.

\begin{tabular}{|c|c|c|c|c|c|}
\hline Candidate Models & $\mathbf{k}$ & AICc & $\Delta \mathrm{AICc}$ & $\omega \mathrm{i}$ & Deviance \\
\hline \multicolumn{6}{|l|}{ Nests } \\
\hline S( $\sim$ wetlands $)$ & 2 & 72.8 & 0 & 0.19 & 68.76 \\
\hline $\mathrm{S}(\sim$ nestage + wetlands $)$ & 3 & 73.5 & 0.69 & 0.13 & 67.42 \\
\hline $\mathrm{S}(\sim$ nestage + wetlands + allstreams $)$ & 4 & 74.3 & 1.55 & 0.09 & 66.24 \\
\hline $\mathrm{S}(\sim$ allstreams $)$ & 2 & 74.5 & 1.72 & 0.08 & 70.48 \\
\hline S( wetlands + lowslope $)$ & 3 & 74.8 & 2.00 & 0.07 & 68.73 \\
\hline $\mathrm{S}(\sim$ nestage + wetlands + lowslope $)$ & 4 & 75.1 & 2.26 & 0.06 & 66.95 \\
\hline$S(\sim 1)$ & 1 & 75.2 & 2.38 & 0.06 & 73.16 \\
\hline $\mathrm{S}(\sim$ nestage + allstreams $)$ & 3 & 75.9 & 3.07 & 0.04 & 69.8 \\
\hline S( nestage $)$ & 2 & 76.0 & 3.16 & 0.04 & 71.92 \\
\hline S( allstreams + swsaplings $)$ & 3 & 76.3 & 3.55 & 0.03 & 70.28 \\
\hline \multicolumn{6}{|l|}{ Adult males and females and fledglings (hy) } \\
\hline $\mathrm{S}(\sim$ swsaplings + hy + female + male $)$ & 5 & 100.2 & 0 & 0.32 & 90.19 \\
\hline $\mathrm{S}(\sim$ hy + female + male $)$ & 4 & 102.0 & 1.8 & 0.13 & 94.02 \\
\hline S( lowslope + allstreams) & 3 & 102.9 & 2.6 & 0.09 & 96.84 \\
\hline $\mathrm{S}(\sim$ time + hy + female + male $)$ & 5 & 103.3 & 3.1 & 0.07 & 93.29 \\
\hline $\mathrm{S}(\sim$ lowslope + hy + female + male $)$ & 5 & 103.9 & 3.7 & 0.057 & 93.88 \\
\hline $\mathrm{S}(\sim$ lowslope $)$ & 2 & 104.0 & 3.8 & 0.05 & 99.98 \\
\hline$S(\sim 1)$ & 1 & 104.1 & 3.9 & 0.05 & 102.09 \\
\hline $\mathrm{S}(\sim \mathrm{SWDI})$ & 2 & 104.1 & 3.9 & 0.05 & 100.13 \\
\hline S( wetlands + lowslope $)$ & 3 & 105.0 & 4.7 & 0.035 & 98.95 \\
\hline
\end{tabular}

Table 5. Parameter estimates, standard error (SE), and lower (LCI) and upper (UCI) confidence intervals for daily survivorship and overall survival; 29 days for nests $(n=37)$, and 60 days for fledglings $(n=18)$ and adult male $(\mathrm{n}=20)$ and female $(\mathrm{n}=11)$ rusty blackbird survival in northern New Hampshire from 2010-2012.

\begin{tabular}{cccccc}
\hline Survivorship Parameters & Survival Estimate & SE & LCI & UCI & Overall \\
\hline Nest survival daily & 0.975 & 0.26 & 0.95 & 0.99 & 0.48 \\
Fledgling survivorship & 0.988 & 0.336 & 0.97 & 0.99 & 0.49 \\
Female survivorship & 0.998 & 0.63 & 0.99 & 1 & $0.89^{1}$ \\
Male survivorship & 0.996 & 0.44 & 0.99 & 1 & 0.79 \\
\hline
\end{tabular}

${ }^{1}$ Female survivorship was estimated with a hypothetical record. See text for details.

Goodness-of-fit values for top habitat selection models were very close to or exceeded our threshold of 0.85 for nest sites (AUC $=0.87$ ), fledglings ( $A U C=0.87$ ), and adults $(A U C=0.84$ ). The Hosmer-Lemeshow test for nests (chi-squared $=9.0, p=0.3$ ) and fledglings (chi-squared $=15.8$, $p=0.051$ ) indicated no lack of fit. However, tests for adults indicated a difference between observed and expected proportions (chi squared $=28.1, p \leq 0.001$ ). In the adult analysis, confidence intervals 
for estimates of two variables in the top model (softwood/mixed-wood sapling stands and low slope) overlapped one and thus were not useful for prediction; estimates for distance to streams in the nest analysis and for low slope in the fledgling analysis were similarly ambiguous (Table 3). The simplified adult model improved the chi-squared to $18.8, p=0.02$. Normal probability and residual plots indicated that all models satisfied assumptions of normality.

\subsection{Blackbird Survival}

Of the 18 fledglings, 20 adult males, and 11 adult females with transmitters in the survival analysis, 7 fledglings (39\%), 5 males (25\%), and 0 females succumbed to mortality during the life of their transmitter. Only one fledgling and one adult blackbird failed to survive the first week after fledging. There were no differences between years, drainages, or seasonal survival. Because the season variable was not important for explaining variation in survival of fledglings, including the period one week after fledging, males, females, and fledglings were analyzed together using age/sex dummy covariates; fledgling sex was unknown. The top model for blackbird survivorship included age and sex categories, with fledglings having the lowest survival rates $(0.988, \mathrm{SE}=0.34)$, males with 0.996, $\mathrm{SE}=0.44$, and females with $0.998, \mathrm{SE}=0.63$ (Table 5).

\section{Discussion}

\subsection{Survival and Habitat Selection}

Rusty blackbirds in our study selected (at a $30 \mathrm{~m}$ radius scale) a combination of habitat conditions for nesting and post-fledging, including shallow wetlands and low slope with softwood/mixed-wood sapling stands. This was the first study to assess the importance of distance to 1 st to 6 th order streams and found that this feature was selected for both nesting and post-fledging. Availability of streams in addition to wetlands may increase foraging opportunities because streams and wetlands have different availability of prey types throughout the season [31,49-52]. Early nestling development may be synchronized with the availability of small items typical of streams, such as Ephemeroptera, Plecoptera, and Trichoptera larvae, while dependent fledglings may require larger Odonata larvae, which are more abundant in wetlands (P. Wohner unpublished data). A diverse network of interconnected channels and impoundments, such as those created by beavers, may provide ideal foraging opportunities for rusty blackbirds [52].

We found that while habitat selection was similar between nest sites and post-fledging locations at the $30 \mathrm{~m}$ scale, the stages had one important difference: wetland cover. Likewise, in a study that included the same drainages, rusty blackbirds did not select wetlands for nesting at the $5 \mathrm{~m}$ scale [29]. At the $500 \mathrm{~m}$ scale, rusty blackbirds were reported more likely to select nesting habitat with increases in wetland cover in New Hampshire [29]. However, the confidence interval for the wetland estimate ranged from -2 to 13 , overlapping 1 , and is therefore inconclusive [29]. We concur that rusty blackbirds select nest sites independent of wetland cover at the 5, 30, or $500 \mathrm{~m}$ scale. However, wetlands are important to adults and fledglings at the $30 \mathrm{~m}$ scale. Concealment from predators may be more important than proximity to foraging areas during nesting and early post-fledging, while foraging opportunities quickly become a priority after fledging [9].

It is likely that proximity to wetlands is important for nest-site selection at a larger scale than has been studied thus far, i.e., >500 m [53]. Rusty blackbirds are highly mobile, traveling up to $2 \mathrm{~km}$ between wetlands and nesting areas, and have large home ranges (3.8-172.8 ha in Maine, equivalent to a circle with radius 35-741 $\mathrm{m}$ [54]). It is possible that cues for selection of nesting and foraging habitat are decoupled at different spatial scales, and rusty blackbirds select wetlands at a $1-5 \mathrm{~km}$ scale for foraging, and nesting habitat at a much smaller scale (0.05-0.5 km [53]). We propose that future nesting habitat selection studies that use multiple spatial scales including the 1-5 km scale would help to determine the density and size of wetlands important for rusty blackbirds at the home range scale and provide better predictive ability for rusty blackbirds [55]. 
Finding the appropriate scale could have important consequences for research and management [55]. For example, many surveys for nesting rusty blackbirds have been wetland-centric and typically only detect songbirds within 100-200 m of a point. In our study, 35 percent of nests were located $>200 \mathrm{~m}$ from the nearest wetland. If rusty blackbird pairs forage at multiple wetlands and streams and nest in relatively distant uplands, wetland-based surveys likely underestimate occupancy and may result in biases [56]. The low detectability documented in other studies that only surveyed wetlands could be a consequence of survey design [28]. Other researchers have noted that point count-based surveys are not well suited for estimating the abundance or habitat use of breeding rusty blackbirds, even when broadcast calls are used [19].

Our nest success estimates (0.48) are well within the range reported by other rusty blackbird researchers $(0.21-0.75 ;$ [27-29]) and are much higher than those reported for red-winged, yellow-headed, and Brewer's blackbirds $(0.30-0.39 ;[30,57])$. Regenerating clear-cuts were suspected ecological traps for nesting in rusty blackbirds in Maine [28]. However, we found evidence that regenerating clear-cuts support successful nesting by rusty blackbirds. Although we did not explicitly test stand origin, nest success did not decrease with increases in softwood sapling stands, $92 \%$ of which originated from even-aged forest management. This result is consistent with other research that found rusty blackbird nest success was independent of recent harvesting [26]. We agree with other researchers that nest success is unlikely to be limiting rusty blackbird populations $[24,26]$.

As in other New England rusty blackbird breeding studies, where nest selection was assessed at 5 and $500 \mathrm{~m}$ radius scales [27,29], rusty blackbirds in our study selected young (5-15 years old) or stunted softwood/mixed wood stands at the $30 \mathrm{~m}$ radius scale for nesting. Many of the New England nesting stands were created by even-aged management and are composed of regenerating softwoods. For example, 75\% of nests in Maine [28], 88\% in Maine and New Hampshire [29], and $92 \%$ in this study were located in young, even-aged softwood stands. While rusty blackbirds seem to have an affinity for regenerating clear-cuts at the 5, 30, and $500 \mathrm{~m}$ scales, there may be a threshold for increasing proportions of regenerating softwood stands at larger scales than $500 \mathrm{~m}$. Blackpoll warblers (Setophaga striata) were found to be positively associated with large proportions of clear-cut at the $115 \mathrm{~m}$ scale [6]. However, at the $1250 \mathrm{~m}$ scale, they were positively associated with clear-cuts only when $<5 \%$ of cover was clear-cut, above which the relationship was negative [6]. Thus, while even-aged forest management may be beneficial for rusty blackbirds at smaller scales, e.g., 5, 30, and $500 \mathrm{~m}$ radius, researchers should consider a scale larger than $500 \mathrm{~m}$ for future studies.

We observed low mortality rates for rusty blackbird fledglings in the first week after fledging $(3 \%)$ compared to those reported for other songbirds, e.g., $21-81 \%$ for ovenbird [2], $11 \%$ for worm-eating warbler [8], and 90\% for rose-breasted grosbeak (Pheucticus ludovicianus) fledglings [7]. All observed fledgling mortality took place in the first four days of a yellow warbler (Setophaga petechi) study [58]. Our high rusty blackbird fledgling survival contrasts with virtually every other songbird post-fledging study. We suggest that dense regenerating softwood stands approximately 5-15 years post-harvest, may afford $<1$-week-old fledglings protection from potential predators while they are most vulnerable. Fledglings of songbirds that nest in mature hardwood stands with relatively open understories have sparse protective cover before moving to early successional habitats with dense vegetation $[1,2,6,12]$. Our overall fledgling survival during the 60-day post-fledging period was also relatively high (0.49) and is likely not an overwhelming factor contributing to population decline. However, we did not study survivorship after fledglings were completely independent from adults, nor during migration when young birds could experience substantial mortality [9]. Populations of fledgling barn swallows (Hirundo rustica erythrogaster) were found to be limited by the pre-migration phase [9].

While few studies have estimated adult survival during either nesting or post-fledging, adult barn swallow survival over 60 days was $0.92, \mathrm{SE}=0.11$ for males and females together [59], compared to our estimates of 0.89 for females and 0.79 for males over the same time frame. Rusty blackbird male survival may truly be relatively low during the post-fledging period. However, the confidence intervals around our estimates are wide (0.54-1), likely due to small sample sizes. Transmitter harnesses may 
reduce survival, resulting in a survival estimate that is lower than actual survival in the general population. We regularly observed rusty blackbirds picking at their harnesses which could distract birds and expose them to higher predation. We have also recaptured blackbirds with transmitters embedded in their skin. Transmitter harnesses have been found to affect survival in sensitive species such as pileated woodpeckers (Dryocopus pileatus; [60]). Why harnesses would have a disproportionate effect on males over females is unknown but could be due to morphological differences between the sexes. High mortality of adult rusty blackbird males during the breeding season seems unusual, but if true, could itself be a key factor in population decline. Male survival during the breeding season warrants future study.

\subsection{Recommendations}

Nest success and adult and fledgling survival were not affected by any of the habitat variables we analyzed, which suggests that something other than breeding ground habitat may be limiting rusty blackbird populations. Thus, we expect that current forest management practices continue to create suitable landscapes for successful nesting and post-breeding survival. Our study adds support to a study in Nova Scotia, that found rusty blackbird habitat remains relatively abundant and well-distributed and is often located in wet lowlands which is a climate-resilient topographic landform [61]. Targeted habitat management for rusty blackbirds is likely to be unnecessary in many areas due to the species' use of regenerating softwood stands that are created by a variety of harvesting practices. We do recommend that harvest plans ensure the availability of at least one softwood stand 5 to 15 years post-harvest within $300 \mathrm{~m}$ of streams and shallow wetlands over time. In the Acadian forest, on ownerships where wildlife habitat is the focus of forest management, prioritizing harvests on poorly drained sites where trees grow more slowly could provide rusty blackbird nesting habitat for longer periods of time ( $\geq 40$ years) [62]).

To aid in finding high priority areas for research or conservation, we recommend overlaying the regression equation from our top models for nests and fledglings in the raster calculator in ARCMAP (i.e., for nests: $-0.87-5.2$ (distance to streams) +0.01 (prop slope) +0.02 (prop softwood/mixed-wood sapling stands). The nests and fledgling models had high goodness of fit, and together, could identify rusty blackbird habitat at the landscape level. We expect our regression equations will be applicable in the southeastern portion of the rusty blackbird's range in Acadian Forest, i.e., New Brunswick, Nova Scotia, northern New England, and the Adirondacks.

Finally, we hope that rusty blackbird researchers will move from traditional survey protocols $[63,64]$ like presence-absence surveys to protocols such as those used for western yellow-billed cuckoos (Coccyzus americanus occidentalis), which also have large home ranges (16-91 ha) [65,66]. These surveys use broadcast calls every $100 \mathrm{~m}$ along transects in appropriate habitat $[67,68]$. (Spring surveys to locate pairs prior to nest searching for intensive research should avoid using broadcast calls, however). Future rusty blackbird research on the breeding ground should incorporate a landscape perspective and include multiple habitat types, including but not limited to dense young softwood stands, streams, seepages, and wetlands. Studying the species at a much larger scale than previously (e.g., $>500 \mathrm{~m}$ ), may shed new light on wetland requirements during nesting.

Author Contributions: Conceptualization, C.R.F. and P.J.W.; methodology, C.R.F. and P.J.W.; formal analysis, P.J.W. and R.J.C.; investigation, C.R.F. and P.J.W.; resources, C.R.F. and R.J.C.; data curation, P.J.W. and C.R.F.; writing-original draft preparation, P.J.W.; writing—review and editing, P.J.W., C.R.F., R.J.C.; visualization, C.R.F. and P.J.W.; supervision, C.R.F.; project administration, C.R.F. and R.J.C.; funding acquisition, C.R.F., R.J.C., P.J.W. All authors have read and agreed to the published version of the manuscript.

Funding: This research was funded by The US Fish and Wildlife Service, New Hampshire Audubon, The Eastern Bird Banding Association, The Smithsonian Institution, The Natural Sciences and Engineering Research Council of Canada, and The University of Georgia.

Acknowledgments: A special thanks to all field assistants who spent considerable time in the clear-cuts and wetlands of New Hampshire from 2010-2012. They include S. Hribal, E. Prohl, R. Rabinovitz, H. Batcheller, E. Dancer, C. Ross, and J. Cosentino. Other supporters include those who granted access to rusty blackbirds on 
their lands including Umbagog National Wildlife Refuge, Wagner Forest Management, Conner, and Plum Creek. S. Edmonds and L. Powell contributed field expertise, on-the-ground assistance, and advice. Members of the International Rusty Blackbird Technical Working Group including L. Powell, S. Edmonds, S. Matsuoka, and D. Tessler provided technical advice on rusty blackbird surveying, nest searching, and capture. V. Jones from New Hampshire Audubon and N. Nibbelink from the University of Georgia assisted with GIS spatial analysis.

Conflicts of Interest: The authors declare no conflict of interest. The funders had no role in the design of the study; in the collection, analyses, or interpretation of data; in the writing of the manuscript, or in the decision to publish the results.

\section{Appendix A}

Summary of rusty blackbirds tagged by year and drainage in northern New Hampshire, USA from 2010-2012; includes total birds and number of points collected, and the subset of blackbirds and telemetry points retained in the analysis by adults $(\mathrm{M}=$ male and $\mathrm{F}=$ female $)$ and fledglings. SWDI $=$ Swift Diamond, MOLL $=$ Mollidgewock, and INTE $=$ Interior .

\begin{tabular}{cccccccc}
\hline Year & $\begin{array}{c}\text { Drainage } \\
\text { Tagged }\end{array}$ & $\begin{array}{c}\text { Total } \\
\text { Birds }\end{array}$ & $\begin{array}{c}\text { Total } \\
\text { Points }\end{array}$ & $\begin{array}{c}\text { Birds in } \\
\text { Analysis }\end{array}$ & $\begin{array}{c}\text { Adults in } \\
\text { Analysis }\end{array}$ & $\begin{array}{c}\text { Fledges in } \\
\text { Analysis }\end{array}$ & $\begin{array}{c}\text { Points in } \\
\text { Analysis }\end{array}$ \\
\hline 2010 & SWDI & 8 & 167 & 4 & $1 \mathrm{M}, 1 \mathrm{~F}$ & 2 & 64 \\
2010 & MOLL & 8 & 130 & 6 & $3 \mathrm{M}, 2 \mathrm{~F}$ & 1 & 73 \\
2010 & 2010 Total & 16 & 297 & 10 & 7 & 3 & 137 \\
2011 & SWDI & 14 & 687 & 10 & $5 \mathrm{M}, 2 \mathrm{~F}$ & 3 & 230 \\
2011 & MOLL & 6 & 120 & 4 & $2 \mathrm{M}$ & 2 & 60 \\
2011 & INTE & 4 & 186 & 4 & $2 \mathrm{M}, 1 \mathrm{~F}$ & 1 & 84 \\
2011 & 2011 Total & 24 & 993 & 18 & 12 & 6 & 374 \\
2012 & SWDI & 12 & 486 & 10 & $5 \mathrm{M}, 4 \mathrm{~F}$ & 1 & 211 \\
2012 & MOLL & 0 & 0 & 0 & 0 & 0 & 0 \\
2012 & INTE & 4 & 89 & 2 & $2 \mathrm{~F}$ & 0 & 49 \\
2012 & 2012 Total & 16 & 575 & 12 & 11 & 1 & 300 \\
Total & & 56 & 1865 & 40 & 331 & 10 & 771 \\
\hline
\end{tabular}

\section{References}

1. Vitz, A.C.; Rodewald, A.D. Can regenerating clearcuts benefit mature-forest songbirds? An examination of post-breeding ecology. Biol. Conserv. 2006, 127, 477-486. [CrossRef]

2. King, D.I.; Degraaf, R.M.; Smith, M.L.; Buonaccorsi, J.P. Habitat selection and habitat-specific survival of fledgling ovenbirds (Seiurus aurocapilla). J. Zool. 2006, 269, 414-421. [CrossRef]

3. Rush, S.A.; Stutchbury, B.J.M. Survival of fledgling hooded warblers (Wilsonia citriana) in small and large forest fragments. Auk 2008, 125, 183-191. [CrossRef]

4. Temple, S.; Cary, J. Modeling the dynamics of forest-interior bird populations in a fragmented landscape. Conserv. Biol. 1988, 2, 305-312. [CrossRef]

5. Faaborg, J.; Holmes, R.T.; Anders, A.D.; Bildstein, K.L.; Dugger, K.M.; Gauthreaux, S.A.; Heglund, P.J.; Hobson, K.A.; Jahn, A.E.; Johnson, D.H.; et al. Recent advances in understanding migration systems of New World land birds. Ecol. Monogr. 2010, 80, 3-48. [CrossRef]

6. Mitchell, G.W.; Taylor, P.D.; Warkentin, I.G. Assessing the function of broad-scale movements made by juvenile songbirds prior to migration. Condor 2010, 112, 644-654. [CrossRef]

7. Moore, L.C.; Stutchbury, B.J.M.; Burke, D.M.; Elliott, K. Effects of forest management on post-fledging survival of rose-breasted grosbeaks (Pheucticus ludovicianus). Auk 2010, 127, 185-194. [CrossRef]

8. Vitz, A.C.; Rodewald, A.D. Influence of condition and habitat use on survival of post-fledging songbirds. Condor 2011, 113, 400-411. [CrossRef]

9. Evans, D.; Hobson, K.A.; Kusack, J.W.; Cadman, M.D.; Falconer, C.M.; Mitchell, G.W. Individual condition, but not fledging phenology, carries over to affect post-fledging survival in a Neotropical migratory songbird. IBIS 2019, 162, 331-344. [CrossRef] 
10. Anders, A.D.; Dearborn, D.C.; Faaborg, J.; Thompson, F.R., III. Juvenile survival in a population of neotropical migrant birds. Conserv. Biol. 1997, 11, 698-707. [CrossRef]

11. Burke, A.D.; Thompson, F.R., III; Faaborg, J. Variation in early-successional habitat use among independent juvenile forest breeding birds. Wilson J. Ornithol. 2017, 129, 235-246. [CrossRef]

12. Marshall, M.R.; DeCecco, J.A.; Williams, A.B.; Gale, G.A.; Cooper, R.J. Use of regenerating clearcuts by late-successional bird species and their young during the post-fledging period. For. Ecol. Manag. 2003, 183, 127-135. [CrossRef]

13. White, J.D.; Gardali, T.; Thompson, F.R., III; Faaborg, J. Resource selection by juvenile Swainson's thrushes during the post-fledging period. Condor 2005, 107, 388-401. [CrossRef]

14. Jenkins, J.M.A.; Thompson, F.R., III.; Faaborg, J. Species-specific variation in nesting and post-fledging resource selection for two forest breeding migrant songbirds. PLoS ONE 2017, 12, e0179524. [CrossRef] [PubMed]

15. Delancey, C.D.; Islam, K. Post-fledging habitat use in a declining songbird. PeerJ 2019, 7, e7358. [CrossRef] [PubMed]

16. Thompson, B.C.; Knadle, G.E.; Brubaker, D.L.; Brubaker, K.S. Nest success is not an adequate comparative estimate of avian reproduction. J. Field Ornithol. 2001, 72, 527-536. [CrossRef]

17. Avery, M.L. Rusty Blackbird (Euphagus carolinus). In The Birds of North America, version 2.0.; Rodewald, P.G., Ed.; Cornell Lab of Ornithology: Ithaca, NY, USA, 2013. [CrossRef]

18. Glennon, M.J. Dynamics of boreal birds at the edge of their range in the Adirondack Park, NY. Northeast. Nat. 2014, 21. [CrossRef]

19. McNulty, S.; Glennon, M.; McCormack, M. Rusty blackbirds in New York State: Ecology, current status, and future. Adirond. J. Environ. Stud. 2015, 20, 87-99.

20. Greenberg, R.; Droege, S. On the decline of the rusty blackbird and the use of ornithological literature to document long-term population trends. Conserv. Biol. 1999, 13, 553-559. [CrossRef]

21. Niven, D.K.; Sauer, J.R.; Butcher, G.S.; Link, W.A. Christmas Bird Count provides insights into population change in land birds that breed in the boreal forest. Am. Birds 2004, 58, 10-20.

22. Sauer, J.R.; Hines, J.E.; Fallon, J. The North American Breeding Bird Survey, Results and Analysis 1966-2005; Version 6.2.; USGS Patuxent Wildlife Research Center: Laurel, ML, USA, 2006.

23. Greenberg, R.; Matsuoka, S.M. Rusty blackbird: Mysteries of a species in decline. Condor 2010, 112, $770-777$. [CrossRef]

24. Greenberg, R.; Demarest, D.W.; Matsuoka, S.M.; Mettke-Hofmann, C.; Evers, D.; Hamel, P.B.; Luscier, J.; Powell, L.L.; Shaw, D.; Avery, M.L.; et al. Understanding declines in rusty blackbirds. In Boreal Birds of North America: A Hemispheric View of Their Conservation Links and Significance; Studies in Avian Biology: 41; Wells, J.V., Ed.; University of California Press: Berkeley, CA, USA, 2011; pp. 107-126.

25. U.S. Fish and Wildlife Service. Birds of Conservation Concern; U.S. Fish and Wildlife Service, Division of Migratory Bird Management: Arlington, VA, USA, 2008.

26. International Union for Conservation of Nature and Natural Resources [IUCN]. Euphagus Carolinus, IUCN Red List of Threatened Species, version 2010. 2; International Union for Conservation of Nature and Natural Resources: Gland, Switzerland, 2010.

27. Matsuoka, S.; Shaw, D.; Sinclair, P.H.; Johnson, J.A.; Corcoran, R.M.; Dau, N.C.; Meyers, P.M.; Rojek, N.A. Nesting ecology of the rusty blackbird in Alaska and Canada. Condor 2010, 112, 810-824. [CrossRef]

28. Powell, L.L.; Hodgman, T.P.; Glanz, W.E.; Osenton, J.D.; Fisher, C.M. Nest-site selection and nest survival of the rusty blackbird: Does timber management adjacent to wetlands create ecological traps? Condor 2010, 112, 800-809. [CrossRef]

29. Buckley Luepold, S.H.; Hodgman, T.P.; McNulty, S.A.; Cohen, J.; Foss, C.R. Habitat selection, nest survival, and nest predators of rusty blackbirds in northern New England, USA. Condor 2015, 117, 609-623. [CrossRef]

30. Martin, T.E. Avian life history evolution in relation to nest sites, nest predation, and food. Ecol. Monogr. 1995, 65, 101-127. [CrossRef]

31. Pachomski, A.L.; McNulty, S.; Foss, C.R.; Cohen, J.; Farrell, S. Rusty Blackbird (Euphagus carolinus) foraging habitat and prey availability in New England: Implications for conservation of a declining boreal bird species. Diversity 2020, 12.

32. Schmidt, K.A.; Rush, S.A.; Ostfeld, R.S. Wood thrush nest success and post-fledging survival across a temporal pulse of small mammal abundance in an oak forest. J. Anim. Ecol. 2008, 77, 830-837. [CrossRef] 
33. Thomas, D.W.; Blondel, J.; Perret, P.; Lambrechts, M.M.; Speakman, J.R. Energetic and fitness costs of mismatching resource supply and demand in seasonally breeding birds. Science 2001, 291, 2598-2600. [CrossRef]

34. Bailey, R.G. Description of the Ecoregions of the United States; 2nd edition revised and expanded. Misc. Publ. No. 1391 (rev.); USDA Forest Service: Washington, DC, USA, 1995.

35. Appalachian Mountain Club. Ecological Atlas of the Upper Androscoggin River Watershed; Appalachian Mountain Club: Boston, MA, USA, 2003.

36. U.S. Climate Data. Available online: https://www.usclimatedata.com/climate/berlin/new-hampshire/unitedstates/usnh0020 (accessed on 14 May 2020).

37. Rappole, J.H.; Tipton, A.R. New harness design for attachment of radio transmitters to small passerines. J. Field Ornithol. 1991, 62, 335-337.

38. Lele, S.R.; Merrill, E.H.; Keim, J.; Boyce, M.S. Selection, use, choice and occupancy: Clarifying concepts in resource selection studies. J. Anim. Ecol. 2013, 82, 1183-1191. [CrossRef]

39. R Core Team. R: A Language and Environment for Statistical Computing; R Foundation for Statistical Computing: Vienna, Austria, 2012.

40. Fieberg, J.; Matthiopoulos, J.; Hebblewhite, M.; Boyce, M.S.; Frair, J.L. Correlation and studies of habitat selection: Problem, red herring or opportunity? Philos. Trans. R. Soc. B 2010, 365, 2233-2244. [CrossRef] [PubMed]

41. Neter, J.; Wasserman, W.; Kutner, M.H. Applied Linear Statistical Models R.D.; Irwin: Homewood, IL, USA, 1990.

42. Burnham, K.P.; Anderson, D.R. Model. Selection and Inference: An Information-Theoretic Approach; Springer: New York, NY, USA, 2002.

43. Royall, R.M. Statistical Evidence: A Likelihood Paradigm; Chapman and Hall: London, UK, 1997.

44. Hosmer, D.W.; Lemeshow, S. Applied Logistic Regression, 1st ed.; John Wiley and Sons: New York, NY, USA, 1989.

45. Ott, R.L.; Longnecker, M. An Introduction to Statistical Methods and Data Analysis, 1st ed.; Wadsworth Group: Pacific Groove, CA, USA, 2001.

46. Laake, J.L. RMark: An R Interface for Analysis of Capture-Recapture Data with MARK; U.S. Department of Commerce: Seattle, WA, USA, 2017.

47. Cooch, E.; White, G. Program. MARK: A Gentle Introduction, 20th ed. 2018. Available online: http: //www.phidot.org/software/mark/docs/book/ (accessed on 1 June 2020).

48. White, G.C.; Burnham, K.P. Program. MARK: Survival estimation from populations of marked animals. Bird Study 1999, 46, S120-S139.

49. Batzer, D.P.; Rader, R.B.; Wissinger, S.A. Invertebrates in Freshwater Wetlands of North America: Ecology and Management; John Wiley and Sons: New York, NY, USA, 1999.

50. Arndt, A.; Domdei, J. Influence of beaver ponds on the macroinvertebrate benthic community in lowland brooks. Pol. J. Ecol. 2011, 59, 799-811.

51. McClure, C.J.W.; Rolek, B.W.; McDonald, K.; Hill, G.E. Climate change and the decline of a once common bird. Ecol. Evol. 2012, 2, 370-378. [CrossRef] [PubMed]

52. Bush, B.M.; Wissinger, S.A. Invertebrates in beaver-created wetlands and ponds. In Invertebrates in Freshwater Wetlands; Batzer, D., Boix, D., Eds.; Springer International Publishing: Cham, Switzerland, 2016; pp. 411-449.

53. Westwood, A.R. Conservation of Three Forest Landbird Species at Risk: Characterizing and Modelling Habitat at Multiple Scales to Guide Management Planning. Ph.D. Thesis, Dalhousie University, Halifax, NS, Canada, 2016.

54. Powell, L.L.; Hodgman, T.P.; Glanz, W.E. Home ranges of Rusty Blackbirds breeding in wetlands: How much would buffers from timber harvest protect habitat? Condor 2010, 112, 834-840. [CrossRef]

55. Bohnett, E.; Hulse, D.; Ahmad, B.; Hoctor, T. Multi-level, multi-scale modeling and predictive mapping for jaguars in the Brazilian Pantanal. Open J. Ecol. 2020, 10, 243-263. [CrossRef]

56. Schaefer, J.A.; Mayor, S.J. Geostatistics reveal the scale of habitat selection. Ecol. Model. 2007, 209, 401-406. [CrossRef]

57. Duquette, C.A.; Hovick, T.J.; Limb, R.F.; McGranahan, D.A.; Sedivec, K.K. Restored fire and grazing regimes influence nest selection and survival in Brewer's Blackbirds Euphagus Cyanocephalus. Acta Ornithol. 2019, 54, 171-180. [CrossRef] 
58. Hepp, M.; Ware, L.; van Oort, H.; Beauchesne, S.M.; Cooper, J.M.; Green, D.J. Postfledging survival and local recruitment of a riparian songbird in habitat influenced by reservoir operations. Avian Conserv. Ecol. 2018, 13, 12. [CrossRef]

59. Gruebler, M.E.; Korner-Nievergelt, F.; Naef-Daenzer, B. Equal nonbreeding period survival in adults and juveniles of a long-distant migrant bird. Ecol. Evol. 2014, 4, 756-765. [CrossRef]

60. Noel, B.L.; Bednarz, J.C.; Ruder, M.G.; Keel, M.K. Effects of radio-transmitter methods on pileated woodpeckers: An improved technique for large woodpeckers. Southeast. Nat. 2013, 12, 399-412. [CrossRef]

61. Bale, S.; Beazley, K.F.; Westwood, A.; Bush, P. The benefits of using topographic features to predict climate-resilient habitat for migratory forest landbirds: An example for the Rusty Blackbird, Olive-sided Flycatcher, and Canada Warbler. Condor 2020, 122. [CrossRef]

62. Burns, R.M.; Honkala, B.H. Silvics of North America: Volume 1. Conifers. In Agriculture Handbook 654; U.S. Forest Service, Department of Agriculture: Washington, DC, USA, 1990.

63. Powell, L.L. Long Term Monitoring Plan for Rusty Blackbirds in the Atlantic Northern Forest; Version 1.8; University of Maine: Orono, ME, USA, 2008.

64. Powell, L.L.; Hodgman, T.P.; Fiske, I.J.; Glanz, W.E. Habitat occupancy of rusty blackbirds (Euphagus carolinus) breeding in northern New England, USA. Condor 2014, 116, 122-133. [CrossRef]

65. Sechrist, J.; Ahlers, D.D.; Zehfuss, K.P.; Doster, R.H.; Paxton, E.H.; Ryan, V.M. Home range and use of habitat of western yellow-billed cuckoos on the middle Rio Grande, New Mexico. Southwest. Nat. 2013, 58, 411-419. [CrossRef]

66. Halterman, M.D. Sexual Dimorphism, Detection Probability, Home Range, and Parental Care in the Yellow-Billed Cuckoo. Ph.D. Thesis, University of Nevada, Reno, NV, USA, 2009.

67. Laymon, S.A.; Halterman, M.D. A Proposed Habitat Management Plan for Yellow-Billed Cuckoos in California. In Proceedings of the California Riparian Systems Conference: Protection, Management, and Restoration for the 1990s, Davis, CA, USA, 22-24 September 1988; Gen. Tech. Rep. PSW-GTR-110; Abell, D.L., Ed.; Pacific Southwest Forest and Range Experiment Station, Forest Service, U.S. Department of Agriculture: Berkeley, CA, USA, 1989; pp. 272-277.

68. Halterman, M.D.; Johnson, M.J.; Holmes, J.A.; Laymon, S.A. A Natural History Summary and Survey Protocol for the Western Distinct Population Segment of the Yellow-Billed Cuckoo; U.S. Fish and Wildlife Service: Washington, DC, USA, 2015; p. 45.

(C) 2020 by the authors. Licensee MDPI, Basel, Switzerland. This article is an open access article distributed under the terms and conditions of the Creative Commons Attribution (CC BY) license (http://creativecommons.org/licenses/by/4.0/). 